\title{
Methodical system of future primary school teachers' research skills development
}

\author{
T.A. $\operatorname{Kot}^{1 *}, I . V$. Zotova $^{2}$, and E.G. Bogoslova ${ }^{3}$ \\ ${ }^{1}$ V.I. Vernadsky Crimean Federal University, Simferopol, Russia \\ 2 State Budget Educational Institution of Higher Education of the Republic of Crimea Crimean \\ Engineering and Pedagogical University the name of Fevzi Yakubov, Simferopol, Russia \\ ${ }^{3}$ State Budget Educational Institution of Higher Education of the Republic of Crimea Crimean \\ Engineering and Pedagogical University the name of Fevzi Yakubov, Simferopol, Russia
}

\begin{abstract}
The article deals with the problem of future primary school teachers' research skills development. The relevance of the studied problem is justified by the need to form the research skills of future primary school teachers, which is one of the requirements of their professional training in higher education formulated in the Federal state educational standard (FSES) and the Professional standard of the teacherteacher of primary school education. The aim of the article was to develop a methodical system of future primary school teachers' research skills development in higher education, as well as process description of its experimental implementation in the educational process of the University. The research methodology includes such methods as pedagogical experiment, diagnostics, approbation, analysis, generalization. In the course of the research the following theoretical results were achieved: the purpose, objectives, components of the methodological system of development, the qualitative result of its implementation, indicated technological support of the process of future educators' research skills development. The results of the study allowed justifying the effectiveness of the developed system of future primary school teachers' research skills development, its theoretical and practical value. The developed methodical system, due to the validity of its effectiveness, can be used in the practice of pedagogical universities in the process of future teachers' readiness to carry out research activities.
\end{abstract}

\section{A problem statement}

One of the most important content components of vocational training of future primary school teachers at the present stage is the development of their research skills [23]. The high level of formation of these skills, in our opinion, will allow solutions to a number of contradictions, namely:

- between the requirements for the implementation of research activities and the real level of readiness of future specialists to it [14];

${ }^{*}$ Corresponding author: ipcs-profped@yandex.ru 
- between the potential of creative preparation of future teachers in higher education and its insufficient implementation [11];

- between the need to improve the level of readiness for research activities of future primary school teachers and the lack of a specific and effective system of their preparation [5];

- between the rapid pace of accumulation of scientific and pedagogical knowledge and the limited capabilities of their mastery by the future specialist [9];

- between the requirements for the activities of future teachers and the internal motives, needs and characteristics of the personality of the students [8].

Based on the above, it is possible to substantiate the need research skills development of future primary school teachers in the process of their professional training in higher education and the development of an effective methodical system for the formation of students' readiness for the implementation of research activities [29].

The purpose of this article is to describe a phased experimental implementation of the methodological system for research skills development of future primary school teachers in the framework of educational process in higher education [31].

\subsection{The objective of the work}

Before turning to the essence of the developed methodological system and the features of its implementation in the educational process of higher education, it is worth clarifying the value of professionally significant skills analyzed in this study. So, A.P. Gladkova interprets research skills as "the ability to organize the actual research activity, select and analyze existing information, independently select and apply research methods and techniques that achieve the desired result" [12].

Scientists V.A. Anisimova and A.A. Nayn by the term "pedagogical research skills" mean "possession of the methods and techniques of research activities that enable one to gain insight into the essence of the proposed solution to the problem and, on this basis, to state and effectively solve scientific and pedagogical problems" (Oros et al., 2018).

N.V. Sychkova emphasizes that pedagogical research skills should be understood as "a person's ability to perform various types of scientific and educational activities acquired by a person based on methodology, methods and techniques".

The author attributes the following research skills:

- abilities and skills of working with scientific literature [26];

- the ability to observe and analyze pedagogical phenomena [1];

- the ability to formulate a hypothesis, set and conduct an experiment [17];

- the ability to process and summarize its results, to summarize the materials in the form of a report [2];

- the ability to learn pedagogical experience [3].

Any pedagogical process will be meaningless in the absence of its final goal [21]. Thus, the main result of the process of formation of research skills of future primary school teachers in the system of their vocational training in higher education is the creation of a specialist's readiness to carry out research activities, including knowledge of ways and methods to attract their pupils to it [6]. The indicators of future primary school teachers' readiness to implement research activities L.P. Shirokova relates to the following:

- presence of elements of a creative and independent search [16];

- ability of students to bring to the study a set of different methods that allow you to get more complete information about the studied phenomena and facts [24];

- methodology to the tasks set adequate choice [6].

The analysis of pedagogical sources allowed substantiating the level of theoretical and practical elaboration of the problem analyzed by us [27]. In studies I.A. Winter presents the 
main theoretical aspects of human research (nature, purpose, objectives, areas, results, components) [30]. In addition, the author considers the characteristics of research activities of students as one of the ways to implement competence-oriented education of future specialists [28]. In the dissertation research LP. Goat research activities of students - future teachers are considered as the leading means of organizing their creative abilities [10]. Based on the analysis of these works, we formulated the goal, objectives and main substantive aspects of the methodological system of future primary school teachers. However, the development of the practical part of the methodical system involved the study of a number of works devoted to the methodological aspects of research skills development of future educators. Based on the analysis of the works of V.A. Anisimova, A.A. Nine, I.Yu. We determined the main directions and substantive aspects of the methodical system for research skills development of students - future primary school teachers, as well as the stages and pedagogical conditions for its practical implementation in the educational process of the university [4].

Based on the study of these scientific papers main components of the methodological system were formulated. However, in our opinion, these studies do not take into account the leading methodological approaches to the implementation of higher professional education at the current stage, and also do not indicate the components of the technological support of the process of future primary school teachers [22]. In this regard, through scientific generalization and synthesis of theoretical and methodological scientific works, we developed the author's methodological system for forming research skills of future primary school teachers, taking into account the provisions of competence, personality-oriented, practice-oriented and humanistic approaches to the implementation of professional training, including the goal, tasks, content components, technological support and the result of the implemented pedagogical process.

\section{Materials and the results of the research}

The approbation of the methodological system was implemented on the basis of the Humanitarian Pedagogical Academy (branch) of FSAE "Crimean Federal University named after V.I. Vernadsky "in Yalta. The 4th year students (49 people) of the Academy of Pedagogical Education (profile "Preschool Education") became respondents of the experimental implementation of the methodical system.

The experiment was conducted during 2017-2018 in three main stages:

- implementation of the primary diagnostics of the level of future primary school teachers;

- introduction of an experimental methodical system;

- conducting a test diagnosis of the level of future primary school teachers.

Basing on the analysis of V.A. Anisimova, I.Yu. Erofeyeva, L.P. Kozlova, A.A. works, we have identified the main principles of the formation of the components of research competence of future teachers in the context of the implementation of the methodological system. Thus, the process of introducing the methodological system for $t$ future primary school teachers was based on the consideration of the following didactic principles:

- the principle of future primary school teachers at the university as an independent and creative specialist, able to manage himself first and then others;

- the principle of transferring students from a contemplative and performing position to the position of an active subject of activity;

- the principle of reliance on the stimulation of research processes;

- the principle of pedagogical reflection;

- the principle of research modeling. 
The effectiveness of the implementation of the methodological system to a certain extent was achieved by complying with the following organizational and pedagogical conditions:

- compliance with the principles of the organization of the educational process;

- to promote students' awareness of the professional and personal importance of mastering research skills;

- development of students' cognitive needs and cognitive interest, instilling interest in the object being studied;

- systematic consideration of the principle of individualization in education;

- the use of technical and visual learning tools;

- systematic use of computer technology training;

- development of creative educational tasks [18];

- inclusion of students in research activities and independent search for sources of information [20];

- a combination of didactically and methodically sound teaching methods that promote the development of students' cognitive activity and creative abilities [19];

- contributing to the accumulation of student experience in the study and analysis of scientific, methodological, normative literature;

- ensuring the possibility of practical implementation by students of the experimental component of their essays, course and diploma projects.

Realizing the ultimate goal of readiness for research activities development, the methodological system of future primary school teachers is based on the introduction of developed workshops, disputes, business games, organizing excursions, searchable independent work, educational research students, scientific and practical conferences into the teaching and educational process, "Round tables", video-methodical trainings and other interactive forms of activity and components of pedagogical technologies, methods of abilities to think creatively development, to defend their own opinion, to implement an independent search and research activities, the ability to quickly make decisions that make up a complex set of research skills [25].

The goal is to improve the training of future primary school teachers for research activities.

Task - future primary school teachers research skills development $t$ and by eagerness to obtain professional research skills.

Components of research skills development:

Motivational and value: of motivational and value attitude to research activities development; activation of cognitive processes

Substantive and procedural: a system of research knowledge and skills development (organizational, analytical, operational, practical and communication); development of pedagogical thinking.

Research: learning and securing ways to carry out research activities; research skills development.

Technological support for future primary school teachers.

Forms: problem lectures; training seminars; practical and individual lessons; conferences; video methodical trainings; teaching and research activities; research activities.

Methods: solving creative problems; heuristic conversation-search; role-playing games; pedagogical experiment; teaching dialogue; partial search; research; creative.

The result - future primary school teachers.

Figure 1 shows the results of our research on the formation of research skills of future teachers.

The experiment was conducted during 2017-2018 in three main stages: 
- implementation of the primary diagnostics of the level of future primary school teachers;

- introduction of an experimental methodical system;

- conducting a test diagnosis of the level of future primary school teachers.

Based on the conducted research on the implementation of an experimental methodological system for future primary school teachers we have achieved quantitative and qualitative results obtained by conducting pedagogical diagnostics. As a result of the primary diagnosis, the majority of respondents to the experiment recorded a sufficient and elementary level of development of research skills. After the implementation of the developed methodological system, most of the participants in the experiment witnessed a sufficient and developed level of development of these skills. By 2019, 35\% of students have developed research skills. Qualitatively, the effectiveness of the methodological system was reflected in the fact that the majority of students noted the presence of motivation for research activities; the main components of the complex research skills and abilities; skills to implement them in contextual practical research and search activities, to use modern technologies for the implementation of research work.

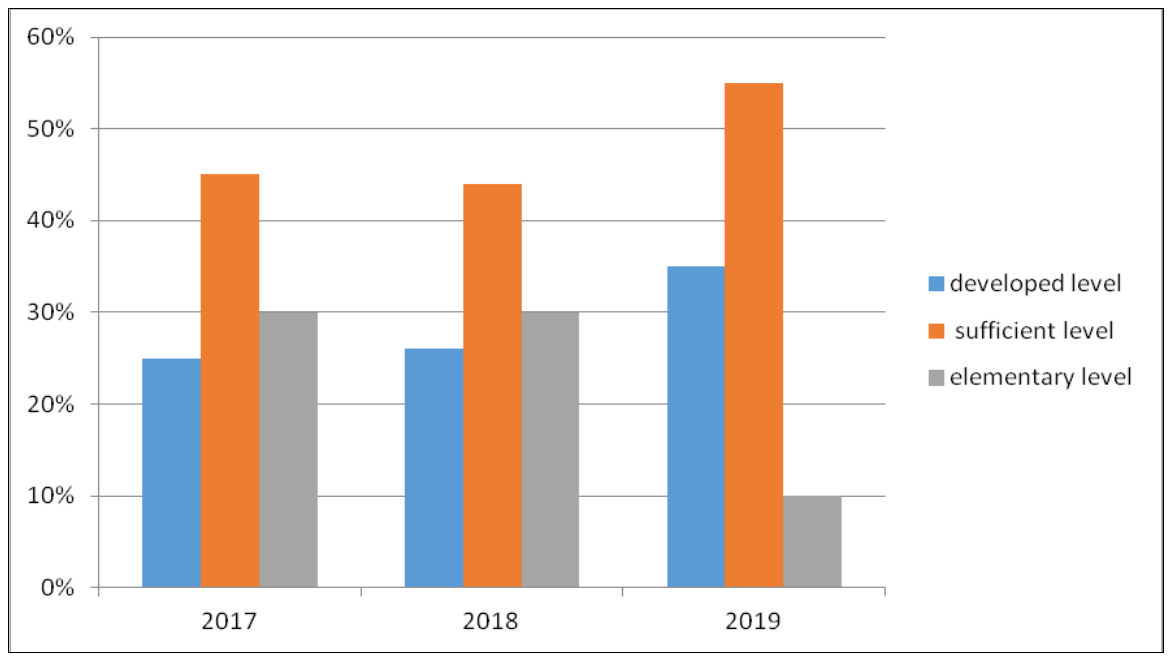

Fig. 1. level of development of research skills (as part of our study).

The foregoing makes it possible to substantiate the effectiveness of an experimental methodological system and the need for its widespread use with the goal of purposefully shaping the readiness of future primary school teachers to implement research activities.

\section{Conclusions}

At the present stage of its development, higher professional pedagogical education is going through a period of modernization. The processes of reorganization and reformation of various components of this system are at the same time beneficial conditions for the improvement of the traditional and the introduction of new experimental methodological systems.

Justifying the need for purposeful formation of readiness of future primary school teachers to research activities, we have developed and implemented a methodical system for the students' research skills development. On the basis of the results of the study, the effectiveness of this methodical system was proved, as well as its theoretical and practical importance in improving the methodological aspects of the implementation of professional 
training of future primary school teachers. . By 2019, 35\% of students have developed research skills. In 2017 , only $10 \%$ of students had this level. The foregoing makes it possible to substantiate the effectiveness of an experimental methodological system and the need for its widespread use with the goal of purposefully shaping the readiness of future primary school teachers to implement research activities.

\section{References}

1. A.N. Chirva, O.G. Chirva, Contents and method of professionally oriented training of informatic disciplines of future teachers of technologies, Scientific Vector of the Balkans, 1, 27-31 (2018)

2. A.P. Cirdan, Innovative technologies of professional training of future economists in the system of continuous education, Humanitarian Balkan Research, 2(4), 27-30 (2019)

3. S.M. Denysenko, Application of quest technology in the professional training Of Bachelor of Publishing and Polygraphy in Higher School, Balkan Scientific Review, 1, 29-33 (2018)

4. S.M. Garnevska, Opportunities for forming communication technology images in training in technology and entrepreneurship, Balkan Scientific Review, 1, 34-37 (2018).

5. H.V. Ihnatenko, K.V. Ihnatenko, Formation of self-dependence as a professional lyimportant personality trait of a future vocational education teacher by means of casetechnology, Humanitarian Balkan Research, 1, 40-42 (2018).

6. L.K. Ilyashenko, M.N. Gladkova, M.M. Kutepov, O.I. Vaganova, Z.V. Smirnova, Development of communicative competencies of students in the context of blended learning, Amazonia Investiga, 8 (18), 313-322 (2019)

7. L.K. Ilyashenko, S.M. Markova, A.G. Mironov, O.I. Vaganova, Z.V. Smirnova, Educational environment as a development resource for the learning process, Amazonia investiga, 8 (18), 303-312 (2019)

8. S.G. Grigoriev, V.A. Shabunina, Ju.M. Tsarapkina, N.V. Dunaeva, Electronic library system as a means of self-development of students of digital generation $Z$ (on the example of studying the course "Basics of the counselor activity"), Scientific and technical libraries, 7, 78-99 (2019)

9. N. Kamenez, O. Vaganova, Z. Smirnova, L. Kutepova, I. Vinokurova, Development of content of educational programs of additional education for professor-teaching composition in organization of educational services of training with disability, Amazonia investiga, 8 (18), 267-278 (2019)

10. A.L. Nikishina, E.M. Kesareva, State and prospects of development of personnel exchange in secondary vocational education,Azimuth of Scientific Researches: Economics and Management,4 (21), 104-108 (2017)

11. N.V. Koshechko, Innovations from educational discipline "Pedagogical conflictology" in professional preparation of students, Scientific Vector of the Balkans, 1, 59-63 (2018)

12. O.M. Kobernyk, N.M. Stetsenko, V.V. Boichenko, S.M. Pryshchepa, Improving professional and pedagogical training of future teachers by moodle platforms (On the example of the course "Pedagogy"), Scientific Vector of the Balkans, 1, 5-7 (2018)

13. I.I. Oros, The role of international connections in the development of the adult education system, Humanitarian Balkan Research, 1, 57-59 (2018) 
14. S.M. Markova, A.K. Narcosiev, Professional education of vocational school students, Vestnik Mininskogo universiteta, 6 (3),(2018)

15. G.A. Pichugina, A.I. Bondarchuk, Structure of the training case in the organization of the educational process, Humanitarian Balkan Research, 2 (4), 5-7 (2019)

16. M.P. Prokhorova, A.A. Semchenko, Involving of trainees-future teachers of professional training in project activities in the discipline, Vestnik Mininskogo universiteta, 6 (2) (2018)

17. V.M. Pliushch, Independent work of students as a factor of improving education quality, Balkan Scientific Review, 1, 69-71 (2018)

18. P.V. Petrichev, N.N. Masyuk, M.A. Bushueva, Method of estimation of the effectiveness of the partnership russian universities with foreign educational organizations, Azimut nauchnykh issledovaniy, 3 (24), 229-232 (2018)

19. I.I. Osadchenko, Key concepts of situational training technology in preparing future teachers, Scientific Vector of the Balkans, 1 (3), 46-49 (2019)

20. J.Raven, Education and Sociocybernetics, Azimut nauchnykh issledovaniy, 3 (20), 289-297 (2017)

21. Ju.M. Tsarapkina, M.M. Petrova, A.G. Mironov, I.M. Morozova, O.B. Shustova, Robotics as a basis for Informatization of education in children's health camp, Amazonia Investiga, 8 (20) (2019)

22. Ju.M. Tsarapkina, N.V. Dunaeva, A.M. Kireicheva, Application of BYOD technology in education on the example of Lecture Racing mobile application, Informatika $\mathrm{i}$ obrazovanie, 9 (308), 56-64 (2019)

23. O.I. Vaganova, E.Yu. Konovalova, N.S. Abramova, A.V. Lapshova, Z.V. Smirnova, Increasing the level of teachers' readiness for pedagogical project, Amazonia Investiga, 8 (22), 286-294 (2019)

24. O.I. Vaganova, I.N. Odarich, A.A. Popkova, Z.V. Smirnova, A.A. Lebedeva, Independent work of students in professional educational institutions, Amazonia Investiga, 8 (22), 295-304 (2019)

25. O.I. Vaganova, S.D. Sirotyk, A.A. Popkova, Z.V. Smirnova, M.N. Bulaeva, Additional education in higher professional educational institution, Amazonia Investiga, 8 (22), 305-310 (2019)

26. O.I. Vaganova, Z.V. Smirnova, M.L. Gruzdeva, Z.V. Chaykina, L.I. Ilyashenko, Development of training content for master students in course "mechatronics and robotics" at the University, Amazonia Investiga, 8 (22), 694-700 (2019)

27. O.I. Vaganova, Formation of competence in the possession of modern educational technologies at a university, Amazonia Investiga, 8 (23), 87-95 (2019)

28. O.I. Vaganova, Organization of practical classes in a higher educational institution using modern educational technologies, Amazonia Investiga, 8 (23), 81-86 (2019)

29. G.A. Vaskovskaya, Features of implementation of pedagogical technologies of profile training, Balkan Scientific Review, 1, 76-79 (2018)

30. N.L. Ivanova, A.A. Korostelev, The impact of competitive approach on students' motivation in sport, Amazonia Investiga, 8 (18), 483-490 (2019)

31. Rakhimbaeva, I.E. Korostelev, A. Shakirova, A. Indira, B. Ayshwarya, Phong Thanh Nguyen, Hashim, Wahidah, Maseleno, Andino, Integration of the Educational and Didactic Systems in the Training of Future Teachers, International Journal of Applied Exercise Physiology, 8 (2.1), 1131-1136 (2019) 